\title{
TOURISM ECONOMIC IMPACT OF SOUTH LAMPUNG REGENCY
}

\author{
Hery Sigit Cahyadi \\ Tourism Destination Studies Department \\ Bandung Institute of Tourism \\ herysigit@gmail.com
}

\begin{abstract}
South Lampung regency as one of the gates of Sumatra Island became one of the many tourist destinations in Indonesia, especially on the island of Sumatra. The existence of tourism activities in South Lampung District economic impacts for the community, such as increasing public income, increased employment and business opportunities for local communities. The purpose of this research is to measure the economic impact of tourism activities in South Lampung Regency. In analyzing the economic impacts of tourism activities in South Lampung District using Keynesian Income Multiplier and multiplier analysis to see the direct impact, indirect impacts, and further impacts. Based on the results of the analysis shows that the presence of tourism activities in South Lampung Regency has had an economic impact on the local economy even though the perceived impact is still small. As evidenced by the value of Keynesian Income Multiplier is 1.95, value ratio Income Multiplier of Type I 1.09, and value ratio Income Multiplier of Type II 1.34.
\end{abstract}

Keywords: South Lampung Regency, Economic Impact, Tourism Activities, Multiplier Effects

\section{INTRODUCTION}

Tourism is one sector of development that can spur economic growth of a region (Soemardjan, 1977:38). Indonesia is currently intensively undertaking development and improvement in the tourism sector. One of the efforts undertaken by the government in development that can meet the inner and outer sufficiency of development in the field of tourism, because with tourism can expand employment opportunities, increase business revenue and also introduce the nature and culture of Indonesia. Indonesia is a tropical country that has beaches, mountains, forests and rivers with abundant natural wealth. According Kreag (2001: 5) "A goal of developing the tourism industry in a community is maximizing positive positive impacts while minimizing potential negative impacts". Tourism as an industry can use the abundance of natural resources, culture wisely and when used wisely it will create a more prosperous society life.

The tourism industry is one of the appropriate means to improve economic progress both locally and globally. As an industry that is currently the mainstay of various countries in the world, tourism becomes one source of foreign exchange income. Increased foreign exchange earnings may have multiple impacts (multiplier effects), the impact can be directly or indirectly, resulting in an impact on the social, cultural, educational and economic fields country (Pitana \& Gayatri, 2005: 110).

National tourism satellite balance data (NESPARNAS) shows that Lampung Province is not yet included into the top ten spending structures tourist archipelago by province provinsi.Province Lampung as one of the gates of Sumatra Island became one of the many tourist destinations in Indonesia, especially in the island of Sumatra whose 
growth is not spared from the main target in the development and development of national tourism among the development of culture and tourism aimed at the improvement of culture and tourism as the main area in advancing economic activity together other fields in accordance with the vision and mission of Lampung Province that is Lampung advanced and prosperous in 2019 with economic improvement and strengthen regional independence.

According to IUOTO (International Union of Travel Organization) quoted from Spilane (1993) states that one of the reasons tourism is developed because tourism can be a trigger for the development of national and international economy. Therefore the economic impact of tourism activities needs to be measured. Mathieson and Wall (2006: 70) states that the economic impact is relatively easier to measure than the physical and socio-cultural impact. Tourism is seen as a field that has strong growth criteria and can have an impact on economic growth from both formal and non-formal fields.

With the increasing number of tourist arrivals coming to South Lampung regency can affect the income of the people of South Lampung regency due to travel activities tourists must spend money taken to buy food, drink, buy souvenirs and so forth. Then anything else can felt by the people of South Lampung Regency indirectly is the creation of new jobs engaged in the tourism sector. From the subject can be affirmed that with the increase of total visits of tourists visiting the District of South Lampung will obviously impacts of tourism activity for the community either from the direct or indirect economical side of the economy (Induce).

Based on the seven aspects of the economic impacts described by Vanhove are limited to two aspects because in general these two aspects have their own effects and benefits for the surrounding community. Revenue or income and employment are the two components that have the greatest impact on the economy. According to Vanhove (2005: 193) "the key elements of the final demand, tourist expenditure (tourism included) and tourism investment, are the basis of two major benefits: income and employment ". The economic impacts of tourism activities in South Lampung Regency are important to measure how much impact society income / income and employment opportunities for local people.

\section{LITERATURE REVIEW}

The high rate of unemployment in a developing country makes research on this economic impact useful. This high unemployment rate makes economic development in a region, especially economic development of the tourism sector can provide jobs and income sources for surrounding communities. Mathieson and Wall (1982: 43) say "One of the first tasks of the economic development is to find gainful employment for all people". Approach of concept theory which done in research about Economic Impact of Tourism of South Lampung Regency is as follows:

\section{Tourism Economic Impact}

According to Mathieson and Wall in Vanhove (2005: 169) there are six components that affect the economic impact of tourism activities:

1. The nature of the main facility and its attractiveness

2. The volume and intensity of expenditure

3. The level of economic development in the destination

4. The size of the economic base of the destination

5. The degree to which tourist expenditures recirculate within the destination

6. The degree to which the destination has adjusted to the seasonality of tourist demand.

Tourism activities that are dynamic and always growing can cause two impacts that are positive and negative impacts. Lickorish (1994) in Mason (2003: 35) argues about the positive economic impact of tourism activities as follows:

1. contribution to foreign exchange earnings 
2. contribution to government revenues

3. generation of employment

4. contribution to regional development

According to Pearce (1989) in Mason (2003: 35) will arise negative economic impact of tourism activities, as follows:

1. Inflation

2. Opportunity Cost

3. Depend on Tourism

All tourism activities in tourism destinations contribute to the impact on the economy in the region. The impact of tourism activities on the economy by Vanhove (2005: 169) is divided into seven categories as follows:

1. Income Generation

2. Employment Generation

3. Tax Revenue Generation

4. Balance Of Payment Effects

5. Improvement Of The Economic Structure Of a Region

6. Encouragement of Entrepreneurial Activity

7. Economic Disadvantages

All components will be too large if to be investigated from tourism activities. Vanhove (2005: 169) argues "The key of the final demand, tourist expenditure (tourism included) and tourist investment, is the basis of two major benefits: income and employment". Pearce minimizes into two components: income / income and jobs.

Pearce's opinion is stated in Mason (2003: 45) that: the study of the impact of tourist development on a destination or destination has been the largest single element of tourism research. much of this predominantly the work of economists and has concentrated on the effects of income and employment.

\section{Income Generation}

Padure and Turtureanu (2005:4) argue that without taking into account receipts from domestc tourism, international tourism receipts alone contribute to a great extent. The low of money generated by tourist spendingx multiplies as it passes through various sections of the economy. According to Sharpley (2006:13) income generation revenue derived from the existence of tourism activities, namely: Travel and tourism is an important source of goverment revenues, while direct tourism expendicture (i.e.tourist receipts) stimulates futher expendicture (hence, income for local businesses) through the multiplier effect.

The presence of tourism activities contributes to income and is classified into two things, direct and indirect income contributions. Tourists who directly visit the destination and spend their money on destinations will be included in the income category direct, while indirect income is secondary effects derived from final demand in the tourism sector on the economy through multiplier effects categorized on indirect income.

Tourism activities in an area have an economic impact which in turn results in the circulation of money sourced from tourist expenditure. The emergence of this circulation is caused by tourists spending a certain amount of money to buy tourism products, whether it is a service product or other product, then the income from the two products will be used again to be used as a cost or capital from the production of products and the production of these service products. Mathieson and Wall (1982: 64) state that multiplier effects in tourism activities are often referred to as circulation of money, "The tourist multiplier can be defined as the initial tourist expenditures must be multiplied in order to obtain the total cumulative income effect for a specified time period ".

Padure and Turtureanu (2005: 4) argue about the multiplier effect "The flow of money generated by spending tourists multiplies as it passes through various sections of the economy through the operation of the multiplier effect". Padure and Turtureanu (2005: 5) tourist expenditure can be analyzed as follows:

\section{Direct Expenditures}

Is tourist expenditure on hotel goods and services and other additions in hotels, restaurants and other tourism facilities such 
as buses, taxis, domestic flights and also includes tourism investments in the region.

\section{Indirect Expenditures}

Is expenditure that covers the total number of inter-business transactions resulting from direct spending, such as the purchase of goods by hoteliers from local suppliers and the purchase of local suppliers from wholesalers.

\section{Continued Expenditures}

Is a tourist expenditure incurred due to additional additional spending resulting from direct spending. For example, hotel workers purchase goods or services using their wages.

From the concepts that have been described, the concept of Padure \& Turtureanu (2005: 5) is used in this study and there are three components in Income, namely:

1. Direct expenditure of tourists

2. Indirect tourist expenditure

3. Continued expenditure of tourists

To measure income generation there are several methods or techniques that can be used according to Vanhove (2005: 193) as follows:

1. The national accounts method (simplified)

2. The Henderson-Cousins method

3. The input-output approach

4. The tourism satellite account

5. The multiplier method

To analyze income generation, the multiplier method or technique needs to be used. This formula illustrates how the value of travelers' continued expenditures can be driven by expenditures made by previous tourists, and shows how economic activities affect the economy at the local level which has the source from tourism activities.

\section{METHODOLOGY}

In this research the method used by writer is descriptive research method with quantitative approach, this research is first processed to draw a conclusion from a research conducted. According to Iskandar in Musfiqon (2012: 61) Quantitative descriptive research is a study to provide a description of symptoms, phenomena, or facts studied by describing the value of independent variables, without intending to link or compare.

The purpose of this study is to describe the economic impact of tourism activities in South Lampung Regency where income generation and employment generation are the focus and are part of the economic impact.

This study uses data sourced from tourists, workers who work in the tourism industry, and tourism industry actors. In accordance with the title of thesis in this study "Tourism Economic Impact of South Lampung Regency" using one variable is the variable of economic impact of tourism from the tourism activity in South Lampung Regency, therein there are two sub variable namely sub variable of Income Generation and sub variable of Employment Generation.

The population in this study is the tourism industry actors located in the South Lampung regency. Tourist Nusantara be an option because it is based on the dominance of the number of tourists visiting the archipelago. For the tourist sample the researcher chooses the accidental sampling technique that is to determine the sample by chance, which means that only those who are incidentally met with the researcher are then selected and / or willing to be elected then can be used as a sample when viewed by the person concerned can be considered appropriate to be used as a data source Kusherdyana and Sulaiman, (2013: 12). For sample business actors and tourism workforce an accidental technique is used where the respondent is selected by chance according to the researcher in the field and then selected and / or willing to choose by researchers. The researchers then used Isaac and Michael's formula to determine the number or size of the sample based on the error rate of $5 \%$. 


\section{RESULT AND DISCUSSION}

\section{Average Holiday Spending}

Calculations about the economic impacts of tourism activities can be made by looking at income generation and employment generation of the tourism sector and then calculating the average total expenditure of tourists as long as the tourists visit a destination. Based on the results of data obtained from research in the field by distributing questionnaires to the domestic tourists amounting to 330 respondents who visited the tourist attraction located in South Lampung Regency then calculated using the formula Tourist Tourist Spending.

$$
\text { Average Spending }=\frac{\text { Total Spending }}{Q}
$$

Information:

Total Spending : Total Tourist Spending

$\mathrm{Q}$ : Total of tourist visitation samples

$$
\begin{aligned}
& \text { Average Spending }=\frac{198,428,000}{330} \\
& \text { Average Spending }=601,296.97
\end{aligned}
$$

During the visit to South Lampung regency, the average amount of tourist spending is Rp. 601.296,97, -

\section{Income Generation}

According to Padure and Turtureanu (2005: 5) there are three aspects In the aspect of income multiplier: direct expenditure aspect, indirect expenditure aspect and expenditure aspect. To measure the impact of tourism activities in South Lampung Regency on the economy of the community there are two types of multipliers, as follows:

a. Keynesian local income multiplier, this type shows how much visitor expenditure has an impact on the increase of local people's income.

b. Ratio Income Multiplier, this type shows how much perceived impact of the expenditure of tourists impact on the local economy. This type measures both indirect and subsequent impacts.

Mathematical formula for Keynesian Income Multiplier and Ratio Income Multiplier as follows: a. Keynisian Income Multiplier = $\frac{D+N+U}{E}$

b. Income Multiplier Ratio Type I = $\frac{D+U}{D}$

c. Income Multiplier Ratio Type II = $\frac{D+N+U}{D}$

Information:

$\mathrm{D}=$ local income earned directly from $\mathrm{E}$ (Rupiah)

$\mathrm{U}=$ local income earned induced from $\mathrm{E}$ (Rupiah)

$\mathrm{E}=$ additional visitor expenses (Rupiah)

$\mathrm{N}=$ local income earned indirectly from $\mathrm{E}$ (Rupiah)

\section{Direct Income Generation}

According to Archer in Mathieson and Wall (2006:110) Direct Income South Lampung Regency's tourism industry is generated from first-time tourist expenditures and it's called direct income generation. The economic impact of tourism activities in South Lampung Regency is measured by overall tourist expenditures such as lodging costs, meals / drinking costs, expenses incurred during travel and other purposes. There are five categories to determine the direct income in the tourism industry is the cost of lodging, food and drink costs, transportation costs, entrance fees and souvenirs. The following is a table of proportion of tourists who visit the District of South Lampung:

Table 1. Proportion of Tourist Spending at South Lampung Regency

\begin{tabular}{lrr}
\multicolumn{1}{c}{ Category } & $\begin{array}{c}\text { Total Spending } \\
\text { (Rupiah) }\end{array}$ & Percentage \\
\hline Accommodation & $58,300,000$ & 29.38 \\
\hline Food and Drink & $48,224,000$ & 24.30 \\
\hline Transportation & $53,511,000$ & 26.97 \\
\hline Entrance Ticket & $15,759,000$ & 7.94 \\
\hline Souvenir & $22,634,000$ & 11.41 \\
\hline \multicolumn{1}{c}{ Total } & $\mathbf{1 9 8 , 4 2 8 , 0 0 0}$ & $\mathbf{1 0 0}$ \\
\hline
\end{tabular}

Expenditure of tourists in South Lampung regency is a big enough money circulation, especially on holidays and weekends. Viewed based on the data table above shows the total of tourist spending obtained from the results of the distribution 
of questionnaires to 330 respondents tourists amounted to Rp. 198.428.000, -.

If the average number of tourist visits to the South Lampung regency per month 46,826 people then the calculation of tourist spending per month of Rp. 28.156.331.900, . The magnitude of the economic impact that occurred due to tourism activities in South Lampung regency can be seen from the amount of money rotation that occurs.

Tourists who make a visit to the South Lampung regency have a need in traveling and these needs can be met by people who run businesses related to the field of tourism. The activity of providing and meeting the needs of travelers with the community raises economic transactions between people and tourists so that people directly feel the direct economic impact of the activity tourism. Local businesses located in South Lampung Regency are mostly medium-scale and crowded buyers only at certain times such as holidays and weekends. The increasing number of tourist visits will also increase the economic activity that comes from expenses incurred by travelers and this will make the amount the velocity of money will increase. Revenue earned by entrepreneurs will respin in this case further used by entrepreneurs as their capital is like to buy raw materials, pay the wage fee labor. Total profit earned by entrepreneurs is the total revenue minus expenses for raw materials and costs wages of labor.

The proportion of revenues of business actors earned from tourist expenditure is $65.04 \%$ and the smallest proportion is the labor wage of $15.09 \%$. In detail can be seen in the following table:

Table2. Business Income Proportion

\begin{tabular}{lc}
\multicolumn{1}{c}{ Component } & Income Proportion (\%) \\
\hline Income & 65.04 \\
\hline Raw materials cost & 19.87 \\
\hline Employee's salary & 15.89 \\
\hline
\end{tabular}

Labor costs are the smallest proportion of this because most entrepreneurs hire labor only at certain times such as weekends and also large holidays that the number of visitors will increase significantly from a typical day. Details of the income of tourism business actors in South Lampung Regency can be seen in the table below, the highest income from tourism businesses in South Lampung Regency is the swimming pool business and the lowest is public toilet effort. Some business actors such as selling souvenirs and food / beverage businesses do not have employees / laborers this is because the scale of business traders are still small medium but not all small scale.

\section{Table 3. Business Income at South} Lampung Regency

\begin{tabular}{lc}
\hline \multicolumn{1}{c}{ Business Unit } & Income/month (Rupiah) \\
\hline Swimming pool & $72,000,000$ \\
\hline Souvenir & $61,800,000$ \\
\hline Restaurant & $56,500,000$ \\
\hline Accommodation & $51,000,000$ \\
\hline Transportation & $16,500,000$ \\
\hline Outbound & $15,000,000$ \\
\hline Food and Beverage & $15,000,000$ \\
\hline Toilet & $2,000,000$ \\
\hline \multicolumn{1}{c}{ Total } & $\mathbf{2 8 9 , 8 0 0 , 0 0 0}$ \\
\hline
\end{tabular}

\section{Indirect Income Generation}

According to Archer in Mathieson and Wall (2006: 110) said that indirect income is the expenditure of the tourism industry in South Lampung district used for labor cost, cost to buy production needs in order to support tourism activity in South Lampung regency. The indirect economic impacts in South Lampung Regency that occur as a result of tourism activities are seen from the proportion of expenditure to buy production needs and the proportion of labor costs incurred by business actors to support tourism activities in South Lampung Regency as shown in the following table:

Table 4. Business Unit Proportion

\begin{tabular}{lcc}
\hline \multicolumn{1}{c}{ Component } & Proportion (\%) & Information \\
\hline Income & 65.04 & businessman \\
\hline $\begin{array}{l}\text { Raw materials } \\
\text { cost }\end{array}$ & 19.87 & businessman \\
\hline Labor cost & 15.09 & businessman \\
\hline
\end{tabular}

Based on the above data the proportion that business actors do is equal to $19.87 \%$ of the proceeds of operations used for the cost of purchasing raw materials. The subsequent 
proportion of $15.09 \%$ of revenues is used by business actors for labor. Not too high proportion on expenditure for raw material cost and also labor cost due to raw material cost in most business actors is durable so the intensity of purchasing is low while for labor wage this is because at some business acter only hire labor at time certain time only.

The indirect economic impact in South Lampung Regency is also seen from salary wages received by the worker which furthermore from the income of labor will be used to buy the material needs and used for other purposes so that this raises the velocity of money which will then become a further impact. The following table data is the average of labor income in Lampung Selatan Regency based on the questionnaire distribution result, as follows:

Table 5. Labor Income

\begin{tabular}{lcc}
\hline \multicolumn{1}{c}{ Unit } & Number & $\begin{array}{c}\text { Labor Income } \\
\text { (Rupiah) }\end{array}$ \\
\hline Employees & 18 & $36,370,000$ \\
\hline $\begin{array}{l}\text { Food and Drinking } \\
\text { Business }\end{array}$ & 8 & $18,380,000$ \\
\hline Transportation & 3 & $5,940,000$ \\
\hline Parking & 3 & $3,000,000$ \\
\hline Outbound & 2 & $3,960,000$ \\
\hline Souvenir Shop & 1 & $1,500,000$ \\
\hline \multicolumn{1}{c}{ Total } & $\mathbf{3 5}$ & $\mathbf{6 9 , 1 5 0 , 0 0 0}$ \\
\hline
\end{tabular}

The above table data shows that there is a diversity in the amount of labor income depending on the type of work undertaken by the community in South Lampung District. Total labor income based on questionnaires distributed to 35 respondents in South Lampung Regency is $\mathrm{Rp}$. 69.150.000, -.

The large number of tourist arrivals in South Lampung regency and the existence of velocity of money that occurs and comes from the expenditure of tourists this will open opportunities business opportunities for people in South Lampung district which then can cause economic activity in South Lampung regency and could cause a more significant economic impact again.

\section{Induced Effect}

The economic impact of tourism activities in South Lampung Regency is not only seen from direct impacts and indirect impacts but also see the continued impacts that result from the tourism activity in South Lampung regency. This continued impact is a further income incurred by the costs incurred by employees working in the tourism sector to meet the needs of life and other needs such as expenditure for consumption including meals and water, school fees, household expenses and transportation costs (Archer in Mathieson and Wall, 2006: 10). In meeting the needs of daily living, most of the local workforce feels inadequate if only relying from the income of work in the field of tourism, therefore most of the labor is looking for side income to meet the needs of life. In table 20 it can be seen that the highest proportion of the percentage is the consumption cost expenditure of $62.47 \%$ it becomes the highest due to the basic needs and also become the main component. The lowest proportion is spending on electricity costs. Here is a table of data on the proportion of labor expenditures.

Table 6. The Proportion of Labor

\section{Expenditure}

\begin{tabular}{lc}
\hline \multicolumn{1}{c}{ Component } & Percentage (\%) \\
\hline Consumption cost & 62.47 \\
\hline Kid's School Cost & 11.89 \\
\hline Electricity Cost & 9.32 \\
\hline Transportation Cost & 16.33 \\
\hline
\end{tabular}

\section{Analisis Multiplier}

To find out how the economic impact arising from the existence of tourism activities in South Lampung regency can be measured from how much tourist spending during the visit in South Lampung regency and calculated the value of multiple effects that occur. There are two ways to measure the economic impacts that result from tourism activities at the local level:

a. Keynesian local income multiplier, this type shows how much visitor expenditure has an impact on the increase of local people's income. 
b. Ratio Income Multiplier, this type shows how much perceived impact of the expenditure of tourists impact on the local economy. This type measures both indirect and subsequent impacts.

Mathematical formula for Keynesian Income Multiplier and Ratio Income Multiplier as follows:

a. Keynisian Income Multiplier $=\frac{D+N+U}{E}$

b. Income Multiplier Ratio Type $\mathrm{I}=\frac{\stackrel{E}{D+U}}{D}$

c. Income Multiplier Ratio Type II $=\frac{D+N+U}{D}$ Information:

$\mathrm{D}=$ local income earned directly from $\mathrm{E}$ (Rupiah)

$\mathrm{U}=$ local income earned induced from $\mathrm{E}$ (Rupiah)

$\mathrm{E}=$ additional visitor expenses (Rupiah)

$\mathrm{N}=$ local income earned indirectly from $\mathrm{E}$ (Rupiah) formula:

Here's the calculationwith multiplier

a. Keynisian Income Multiplier: $\frac{289,800,000+69,150,000+28,500,000}{198,428,000}=1.95$

b. Income Multiplier Ratio Type I: $\frac{289,800,000+28,500,000}{289,800,000}=1.09$

c. Income Multiplier Ratio Type II: $\frac{289,800,000+69,150,000+28,500,000}{289,800,000}=1.34$

Table 7. Multiplier Results From The Velocity of Money

\begin{tabular}{clc}
\hline No & \multicolumn{1}{c}{ Criteria } & Value \\
\hline 1 & Keynisian Income Multiplier & 1.95 \\
\hline 2 & Income Multiplier Ratio Type I & 1.09 \\
\hline 3 & Income Multiplier Ratio Type II & 1.34 \\
\hline
\end{tabular}

Based on the calculation with the above formula obtained the amount of economic impact caused by the tourism activity in South Lampung regency, the value for the Keynesian income multiplier is 1.95 so that every tourist spending of Rp. 100,000, - will have an impact economy and income in the community will increase by Rp. 195.000 ,.

The effect of the velocity of money issued by tourists also cause economic impacts felt by business actors in the form of income and profit from business results then the economic impact that arises also felt by local workers in the form of salary wages from where he works. Value of Income Multiplier Ratio Type I is 1.09 so that every tourist spending of Rp. 100,000 will cause an economic impact of Rp. 109,000 to direct and indirect impacts (sourced from the income of business actors and wages received by workers). Then the value of Ratio Income Multiplier Type II is 1.34 so that every tourist spending of Rp. 100.000, will cause an economic impact of $\mathrm{Rp}$. 134.000, - which is a direct impact and induced impact as the source (income of business actors and expenses for labor consumption costs).

The values obtained above have criteria for determining whether or not the economic impacts arising from tourism activity in the area, as described by Marine Ecotourism for Atlantic Area (2001) in the Milestari criteria are:

a. If the value is between zero and one $(0<\mathrm{x}$ $<1)$ then the area has been economic impact of tourism activity but low c. If the value is greater or equal to one $(=1)$ then the tourist area has contributed in the form of economic impact of tourism activity.

b. The values contained in the above results is a picture of the economic impact derived from the expenditure of tourists to the income for business actors and workers especially in the field of tourism located in South Lampung regency. Referring to the theory of Marine Ecotourism For Atlantic Area (2001) in Milasari that the calculation results of the three aspects of multiplier calculation obtained results that is greater than the number one which means tourism activity in South Lampung regency provides economic impact on the community. This research on economic impact is in line with research on the economic impacts arising from tourism activities and contributes to the local economy. The 
table below is an empirical study of the economic impact.

Table 8. Economic Impact Contribution From Tourism Activities at South Lampung

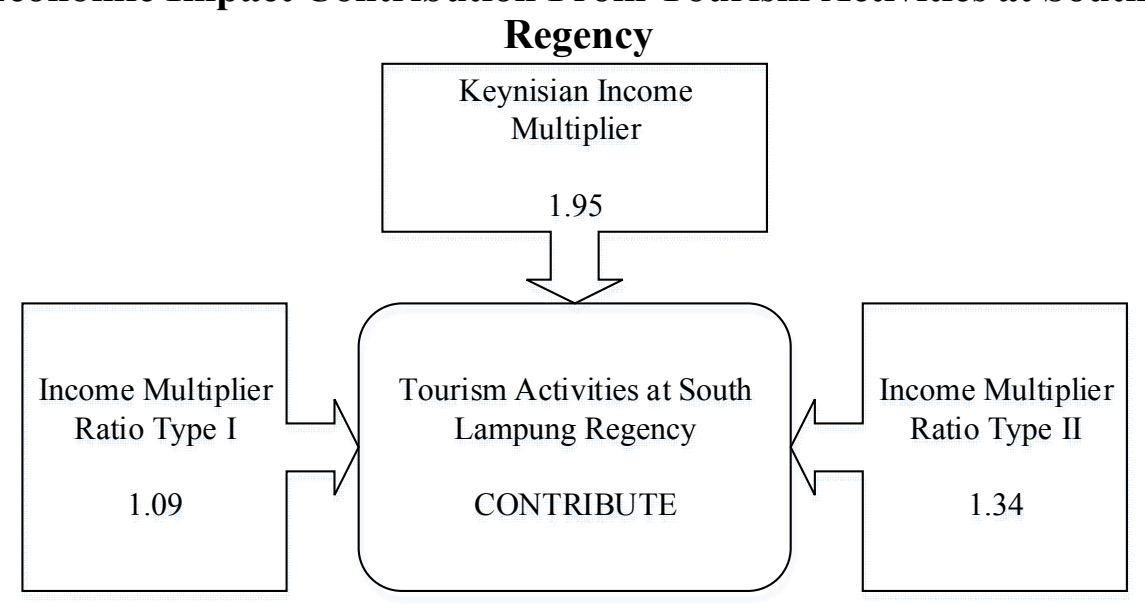

\section{Employment Lampung}

Tourism activities generate economic impacts thus forming opportunities for employment opportunities for the community. To analyze it is used multiplier method is the comparison between direct and indirect employment that comes from the expenditure of tourists.

The systematic formula:

$$
\mathrm{Ek}=\frac{(\text { Direct }+ \text { Indirect Employment })}{\text { Expenditure }}
$$

Information:

Direct: Direct Labor related to tourism sector

Indirect: Labor who work at supporting tourism business sector

The formula is a comparison of the number of workers whose types of work are directly related to tourists and not directly associated with tourists then divided by the number of tourists who visit the visit to South Lampung regency. Here is the calculation of the analysis that make up employment as the effect of tourism activity in South Lampung Regency:

$=\frac{(121,752)}{198,428,000}$

$=0.0006135$

The analysis results obtained that every tourist spending Rp. 1, - gives the effect of job opportunity for 0.0006135 workforce in South Lampung District. When the tourists who visit the South Lampung regency and make expenditures per one visit

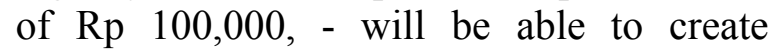
employment opportunities for 61.35 percent of new workforce in tourism. The overall result of the analysis on the economic impact of tourism in South Lampung Regency shows that the existence of tourism activities in South Lampung Regency has not given maximum contribution to the economy of the community.

\section{CONCLUSION}

With the presence of tourism activities in South Lampung regency it raises the economic activity that affects the economy of the community in South Lampung regency. The increasing number of tourist arrivals to the southern Lampung regency in each year to prove that there has been a tourism activity that gives economic impact. The results of observations by researchers in the field obtained data on the number of tourist visits in South Lampung regency in 2016 amounted to 561,919 tourists.

The number of visits has an influence on the economy in Lampung Selatan Regency either directly, indirectly and continuously. From the results of questionnaires distributed to 330 respondents in South Lampung regency, the average of tourist spending during visit to South Lampung regency is $\mathrm{Rp}$. 601.296,97. 
Measurement of income generation and employment generation arising from tourism activities in South Lampung Regency must first know about income multiplier and employment multiplier where mulitplier income is a multiplier obtained from direct income, indirect income and income continued.

Then the employment multiplier is a multiplier generated from jobs directly related to tourists and jobs that are not directly involved with tourists. By using multiplier method of economic impact that happened in Lampung Selatan Regency measured how big impact.

The value for the Keynesian income multiplier is 1.95 so that every tourist spending is Rp. 100.000, - will cause economic impact and income on society will increase equal to Rp. 195.000, -.

The value for the Ratio Income Multiplier Type I is 1.09 so that every tourist spending is Rp. 100,000 will cause an economic impact of Rp. 109,000 of direct and indirect impacts (sourced from the income of business actors and wages received by workers).

The value for the Ratio Income Multiplier Type II is 1.34 so that every tourist spending is Rp. 100.000, - will cause an economic impact of Rp. 134.000, - which is a direct impact and induced impact as the source (income of business actors and expenses for labor consumption costs).

The analysis results obtained that every tourist spending Rp. 1, - gives the effect of job opportunity for 0.0006135 workforce in South Lampung District. When the tourists who visit the South Lampung regency and make expenditures per one visit of $\mathrm{Rp}$. 100,000 , - will be able to create employment opportunities for 61.35 percent of new workforce in tourism.

\section{REFERENCES}

Kreag, G. (2001). The Impacts of Tourism. Minnesota: University of Minnesota Press

Kusherdyana, \& Sulaiman, S. (2103). Pengantar Statistika Pariwisata Aplikasinya Dalam Bidang: Pariwisata, Usaha Perjalanan, Dan Perhotelan. Bandung:Alfabeta.

Mathieson, A., \& Wall, G. (2006). Tourism: Changes, Impact And Opportunities. Harlow: Pearson Prentice Hall.

Mathieson \& Wall. (1982). Tourism: Economic, Physical and Social Impact. New York: Longman Scientific and Technical.

Marine Ecotourism for Atlantic Area. (2001). Planning for marine ecotourism in the EU Atlantic Area. Bristol (ID): University vof the West of England.

Mason, Peter. (2003). Tourism Impacts, Planning and Management. Oxford: Butterworth-Heinemann.

Musfiqon, H. (2012). Metodologi Penelitian Pendidikan. Jakarta: Prestasi Pustaka

Padure, G., \& Turtureanu, I. A. (2005). Economic Impact of Tourism. Oeconomica, 1, 129-140.

Pitana, I., \& Gayatri, P. (2005). Sosiologi Pariwisata. Yogyakarta: Andi.

Sharpley, Richard. (2006). Travel and Tourism. New York: SAGE Publications.

Spillane, James. (1993). Ekonomi Pariwisata, Sejarah dan prospeknya. Yogyakarta: Kanisius.

Vanhove, N. (2005). The Economics Of Tourism Destinations. Oxford: Elsevier. 